\title{
Представления о будущем родительстве в подростковом и юношеском возрасте
}

\section{Елена И. Захарова“, Ольга А. Карабанова, Юлия А. Старостина, Александра Г. Долгих}

Московский государственный университет имени М. В. Ломоносова, г. Москва, Российская Федерация

*E-mail: e-i-z@yandex.ru

\begin{abstract}
Аннотация
Введение. В статье обосновывается актуальность исследования представлений о будущем родительстве. Новизна исследования заключается в выявлении сенситивного периода спонтанного становления представлений о родительстве; показано, что при переходе от подросткового возраста к юношескому происходит существенный сАвиг в сторону их гармонизации.
\end{abstract}

Методы. Описываются Методики исследования: 1) авторский опросник «Гармоничность преАставлений о родительстве», направленный на определение содержания и степени адекватности представлений о будущем родительстве; 2) метолика «Неоконченные преАложения», выявляющая представления респонАентов о родительстве, отношение к родительству в целом и себе как к будущему родителю; 3) методика «Материнские роли», выявляющая наиболее предпочитаемые материнские роли.

Результаты. РазАел включает описание и сравнение содержания представлений о родительстве у подростков и юношей. В целом по выборке зафиксированы низкие значения гармоничности представлений. Также наблюАаются значимые различия по всем параметрам гармоничности межАу двумя сравниваемыми группами: преАставления школьников о родительской позиции, среАствах воспитания менее алекватны и приближены к реальности, чем у молоАых ^юАей. А^я поАростков характерно амбивалентное отношение к родительству в целом, четверть всей выборки негативно относится к перспективе собственного родительства. Наиболее преАпочитаемыми Аля поАростков стратегиями реализации материнских ролей стали те, в которых принимается приоритет потребностей ребенка, гармоничное сочетание материнской роли и супружеской.

ОбсужАение результатов. Авторы рассматривают полученные результаты С точки зрения эфрфективности использованных среАств, сравнивают их с Аанными, полученными в Аругих исслеАОваниях. Аелаются выводы: о низкой гармоничности преАставлений о роАительстве У поАростков и молоАЫх АюАей; о наличии значимых различий в преАставлениях о роАительстве при перехоле от поАросткового 
к Юношескому возрасту; о наличии гендерных различий в представлениях о родительстве; о наиболее привлекательном образе будущей матери и связи ценностных ориентаций с представлениями.

\section{КАючевые слова}

преАставления о ролительстве, полростковый возраст, юношеский возраст, гармоничность преАставлений, аАекватность преАставлений, полнота преАставлений, родительские функции, среАства воспитания, отношение к родительству, материнские роли

\section{Основные положения}

- представления о буАущем родительстве и у полростков, и у студенческой мо^оАежи отличаются низкой гармоничностью;

- наблюлаются возрастные различия: представления о будущем родительстве в юношеском возрасте приобретают большую определенность и алекватность; зафиксирована гендерная специфрика представлений;

- полростковый возраст может быть определен как сенситивный Аля гармонизирующего возАействия, провеАения профрилактической работы по усилению привлекательности буАущего родительства;

- в качестве илеального образа женщины-матери Аля всей выборки выступает та, что в наибольшей степени реализует функцию заботы и полАержки ребенка.

\section{Для цитирования}

Захарова Е. И., Карабанова О. А., Старостина Ю. А., Долгих А. Г. Представления о будущем родительстве в подростковом и юношеском возрасте // Российский психологический журнал. 2019. Т. 16, № 2. С. 103-122. doi: 10.21702/rpj.2019.2.6

Материалы статьи получены 01.09.2018

UDC 159.9.072.432

doi: $10.21702 /$ rpj.2019.2.6

\section{Ideas on Future Parenthood in Adolescents and Young Adults}

Elena I. Zakharova*, Olga A. Karabanova, Yuliya A. Starostina, Aleksandra G. Dolgikh

Lomonosov Moscow State University, Moscow, Russian Federation

*Corresponding author. E-mail: e-i-z@yandex.ru 


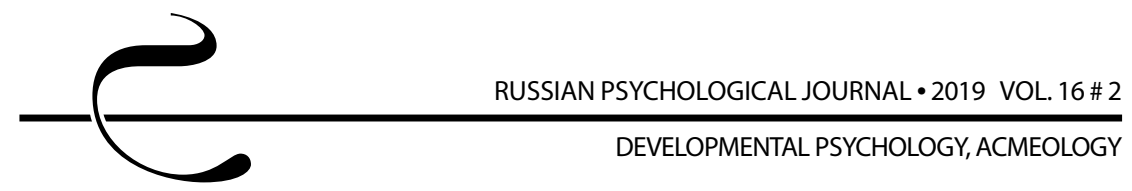

Abstract

Introduction. Studying ideas about future parenthood has been gaining importance in recent years. This study focuses on the sensitive period of the spontaneous formation of ideas about parenthood and explains a fundamental shift towards their harmonization during the transition from adolescence to young adulthood.

Methods. The study used the following techniques: (a) the Consistency of Ideas About Parenthood questionnaire developed by the authors to reveal the content and the degree of adequacy of ideas about future parenthood; (b) the Unfinished Sentences technique to reveal respondents' ideas about parenthood, their attitudes towards parenthood, and self-attitudes as future parents; and (c) the Maternal Roles technique to identify the most preferred maternal roles.

Results. This section describes and compares the content of ideas about parenthood in adolescents and young adults. The values of the consistency of ideas were low in the whole sample. Besides, there were significant differences between the two compared groups regarding all the parameters of consistency. Compared to young adults, schoolchildren had more adequate and realistic ideas about parental positions and means of parenting. Ambivalent attitudes towards parenthood as a whole were characteristic of adolescents. About 25 percent of all the respondents had negative attitudes towards their future parenthood. Orientation towards children's needs and harmonious combination of maternal and spousal roles underlay the strategies of the realization of maternal roles that were mostly preferred by adolescents.

Discussion. The authors interpreted the findings in terms of the effectiveness of the used means and compared them to data from previous studies. The authors draw conclusions about (a) low consistency of ideas about parenthood among adolescents and young adults, (b) significant differences in ideas about parenthood during the transition from adolescence to young adulthood, (c) gender differences in ideas about parenthood, (d) the most attractive image of future motherhood, and (e) correlations between value orientations and ideas about parenthood.

\section{Keywords}

ideas about parenthood, adolescence, young adulthood, consistency of ideas, adequacy of ideas, completeness of representations, parent functions, means of parenting, attitudes towards parenthood, maternal roles

\section{Highlights}

- Adolescents and young adults' ideas about future parenthood exhibit low consistency. Age-related differences in ideas about future parenthood are found; more clear and adequate ideas about future parenthood are characteristic of young adults.

- Gender characteristics of ideas about parenthood are described.

- Adolescence can be defined as a sensitive period for harmonizing influences and 
the implementation of preventive measures for increasing the attractiveness of future parenthood.

- The image of the mother that cares and supports her child is the ideal mother image for all the respondents.

\section{For citation}

Zakharova, E. I., Karabanova, O. A., Starostina, Yu. A., \& Dolgikh, A. G. (2019). Ideas on Future Parenthood in Adolescents and Young Adults. Rossiiskii psikhologicheskii zhurnal (Russian Psychological Journal), 16(2), 103-122. (in Russ.). doi: 10.21702/rpj.2019.2.6

Original manuscript received 01.09.2018

\section{Введение}

На современном этапе развития российского общества наблюдается рост неблагоприятных тенденций, связанных с отношением к родительству. В работах Васягиной (2011), Филипповой (2005), Захаровой (2015), Мухиной, Белогай (2007) отмечается неготовность молодых женщин к материнству, к выполнению родительских обязанностей, к принятию материнской роли. В ряде исследований описывается несовпадение ожиданий молодых родителей и реальной практики отцовства и материнства (Delmore-Ko, Pancer, Hunsberger, \& Pratt, 2000; Левченко, 2009), поднимаются проблемы современного родительства, в том числе и этического характера, свидетельствующие об изменении института семьи (приемное родительство, суррогатное материнство и т. д.) (Richards, 2010; Salmela-Aro, Nurmi, Saisto, \& Halmesmäki, 2000; “Modern Parenthood...," 2013). Поливанова указывает на снижение привлекательности родительской деятельности (2015), Долгих и Захарова описывают неполноту и дисгармоничность представлений о родительстве у молодежи (2018). Даже состоявшиеся родители испытывают трудности в принятии родительской роли (Захарова, 2014), во взаимодействии с детьми (Cudmore, 2012; Arendell, 2000), ощущают тревожность и неуверенность относительно своего родительского поведения («Психология родительства: подходы, проблемы, методы...», 2006). Если же такие тревожные переживания и неуверенность присутствуют в период личностного самоопределения молодого человека, это существенно влияет на его репродуктивное поведение.

Родительство имеет свою историю становления, освоение родительской роли начинается задолго до появления собственных детей. Филиппова (2002, 2005) предлагает оригинальную концепцию онтогенеза материнства и отцовства. В условиях традиционного общества существовала преемственность между поколениями, к взрослости у девушек и юношей уже был необходимый опыт нянченья, ухода и воспитания. Сегодня же зачастую родительские 
роли и родительская деятельность осваиваются спонтанно, без специальной подготовки. Нередко случается, что первый младенец, которого держат на руках молодые родители - это их собственный ребенок. Это порождает неуверенность в себе как в родителе (Захарова, 2014; Hakim, 2003), а также существенную неполноту и дисгармоничность представлений о собственном ребенке (Oechsle \& Zoll, 1991) и родительстве (Долгих и Захарова, 2018; Langdridge, Sheeran, \& Connolly, 2005). В работе Абдуллиной (2018) было показано, что подростки с тревогой относятся к своему будущему родительству, даже несмотря на желание иметь детей в будущем. В то же время в современном обществе ценность родительства самого по себе снижается, вступая в противоречие с самореализацией в карьере, успешностью, стремлением к гедонизму и т. д. Девятых (2006) пишет, что родительство представляется юношам и девушкам препятствием на пути самореализации, создающим необходимость жертвы и самоотречения.

Данная ситуация определяет актуальность изучения условий становления отношения к родительству у современной молодежи, поиск путей его гармонизации. Одним из таких условий является содержание представлений о родительстве. Именно представление о будущей родительской роли становится отправной точкой для формирования внутренней позиции в отношении будущего материнства, отцовства. Представления о родительстве формируются на основе имеющегося у человека жизненного опыта (прежде всего в родительской семье) (Мерзлякова, 2014; Манёров, 2013) путем его воспроизведения в воображении (Овчарова, 2005) и могут включать в себя установки, ценности, представления и ожидания, связанные как с ребенком, так и с собой как будущим родителем («Родители и дети: психология взаимоотношений...», 2003). Мы рассматриваем родительские представления как ориентиры, с опорой на которые человек будет строить свое родительское поведение в будущем. Опираясь на идеи Гальперина о том, что психический образ выполняет важную функцию в процессе ориентировочной деятельности субъекта, мы предполагаем, что представления о родительстве становятся средством ориентирования в реальной деятельности материнства или отцовства в период ее освоения. Соответственно, и родительство понимается нами как особый вид человеческой деятельности, имеющий органические предпосылки и культурную природу (Захарова, 2012; Карабанова, 2005).

Большинство исследователей справедливо обращается к подростковому и юношескому возрасту, как возрастным периодам, в которых происходит развитие самосознания, появляется способность к самопознанию и рефлексии, происходят становление идентичности и выработка собственной позиции по всем жизненно важным вопросам, в том числе и относительно собственного будущего материнства или отцовства (Мерзлякова, 2014; Крысько 
и Ланцбург, 2014; Павлова, 2011). Эти представления будут дополнены и реализованы на следующих возрастных этапах, но их становление и осознание происходят именно в подростковом возрасте (Филиппова, 2002).

В исследовании Пальцевой (2006) о формировании репродуктивных установок у детей было показано, что репродуктивные установки к концу подросткового возраста (18 лет) уже являются сформированными, и их содержание начинает определять репродуктивные намерения человека.

В исследовании Абдуллиной (2018) было показано, что подростковый возраст является сенситивным периодом для формирования когнитивного компонента представлений о родительстве, а ранняя юность - для поведенческого компонента. Когнитивный компонент - это образ ребенка, образ себя как родителя, представления и ожидания относительно родительства, представление о родительских функциях и особенностях ребенка разного возраста; поведенческий компонент - это способы реализации родительских функций, умения и навыки по уходу, общению с ребенком, воспитанию и обучению ребенка. То, что описывается выше как «когнитивный компонент» представлений о родительстве, отражает структуру родительской деятельности, выступает ее ориентировочной частью.

Представления о будущем материнстве и отцовстве в подростковом возрасте изучены не достаточно полно, гораздо больше исследований аналогичной тематики относительно юношеского возраста. В нашей работе мы обратились к истокам представлений, к тому моменту, когда впервые на основании личностной рефлексии эти представления начинают осознаваться, что создает условия для становления отношения к родительству. Нам представляется перспективным изучение представлений о родительстве у современных подростков, выявление их возрастной специфики в связи с возможностью оказания гармонизирующего психологического воздействия. Практическая значимость данной работы заключается в поиске сенситивного момента для такого воздействия, благоприятного периода для формирования адекватных и гармоничных представлений о родительстве у современной молодежи.

Целью нашего исследования является изучение возрастной специфики представлений о родительстве в подростковом и юношеском возрасте в условиях их спонтанного становления.

\section{Методы}

1. Авторская методика «Гармоничность представлений о родительстве» опросник из 40 утверждений, составляющих 5 шкал. Все утверждения касаются будущего родительства респондента. Предполагаемый возраст ребенка, на который предложено ориентироваться респондентам, не превышает 9 лет. 


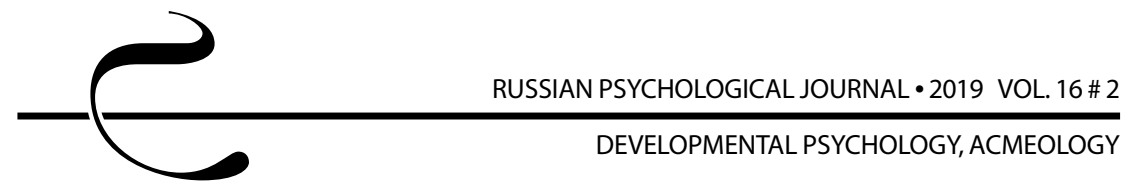

Шкалы опросника:

- адекватность позиции родителя (шкала направлена на определение степени адекватности представлений о себе как родителе, родительской позиции, предполагающей руководящую роль взрослого человека);

- адекватность средств воспитания (шкала направлена на определение степени адекватности выбираемых для достижения целей воспитания средств);

- реалистичность представлений (шкала фиксирует степень реалистичности представлений о себе в роли родителя, выявление возможной идеализации образа ребенка и своего родительства);

- учет возрастных особенностей ребенка (шкала направлена на установление степени адекватности представлений о возрастных особенностях ребенка);

- сбалансированность родительских функций (шкала фиксирует наличие баланса между эмоциональным принятием («любовь к ребенку») и основными родительскими функциями (уход, обеспечение развития, воспитание ребенка)).

2. Неоконченные предложения, авторский набор из 16 предложений, описывающий 4 шкалы:

- отношение к родительству (мы выделили 4 типа отношения к родительству: нейтральное, негативное, амбивалентное и позитивное);

- отношение к себе как к родителю (также были выделены 4 типа отношения: нейтральное, негативное, амбивалентное, позитивное);

- ценностная направленность (мы выделили 3 типа ценностной направленности респондентов: превалирование ценности родительства, сочетание ценности родительства с другими сферами жизни, отчетливое превалирование другой ценности);

- представления о родительстве (были выделены 3 типа представлений: гармоничные, отличающиеся неполнотой и дисгармоничные).

На основе соотнесения оценок по 4 предложениям внутри каждой шкалы делался вывод о превалировании того или иного типа отношения или представлений.

3. Методика «Материнские роли», позволяющая выявить место материнства в ролевой структуре женщины-матери. Респонденту предлагается серия из 5 картинок, на которых изображены матери, различающиеся по характеру реализации материнской роли:

- «мама заботливая» (обеспечение функции заботы о ребенке становится центральным в период материнства);

- «мама деловая, занятая» (материнская роль сочетается с профессиональной позицией женщины); 
- «мама хозяйственная» (материнство дополняется осуществлением хозяйственных функций);

- «мама общительная» (реализация материнской роли встраивается в сферу межличностного общения женщины вне семьи);

- «мама-жена» (сочетает в себе сферы родительских и супружеских отношений).

Респондентам было предложено выбрать и проранжировать изображения по степени их привлекательности.

\section{Выборка исследования}

В нашем исследовании приняли участие 68 респондентов (29 старшеклассников - девочек и мальчиков от 15 до 17 лет, и 39 молодых людей - девушек и юношей от 19 до 30 лет). Принявшие участие в исследовании подростки были учениками 9-го и 11-го классов МОУ СОШ № 29 им. П. И. Забродина (г. Подольск, Московская область). Молодежная выборка состояла из студентов МГУ имени М. В. Ломоносова и МГТУ имени Н. Э. Баумана, обследование которых проводилось в рамках учебного процесса.

\section{Результаты}

Проведенный в ходе исследования анализ представлений о родительстве у подростков и молодых людей в период вхождения во взрослость позволил выделить ряд особенностей, характерных для каждого возрастного периода. Так, по результатам методики «Гармоничность представлений о родительстве», были зафиксированы значимые различия ( $p<0,01$ по Т-критерию для 2-х независимых выборок: по шкале «адекватность родительской позиции» $\mathrm{T}=-2,349 ;$ по шкале «адекватность средств» $\mathrm{T}=-11,987 ;$ по шкале «реалистичность представлений» $\mathrm{T}=-3,038$; по шкале «учет возраста ребенка» $\mathrm{T}=-2,354$; по шкале «сбалансированность родительских функций» $T=-8,270)$ по всем показателям между опрашиваемыми группами респондентов (рис. 1).

Максимум, который может набрать респондент по каждой из шкал,24 балла (абсолютная гармоничность представлений), минимум - 8 баллов (абсолютная дисгармоничность представлений). На рисунке видно, что представления школьников о родительской позиции, средствах воспитания менее адекватны и приближены к реальности, чем у молодых людей. Так, оценивая справедливость утверждений относительно специфики социальной позиции родителя, они часто соглашаются с тем, что «ребенок в семье имеет точно такие же права, что и родители» или «родитель и ребенок - в первую очередь друзья». В то же время они склонны не соглашаться с тем, что «родитель имеет право ограничивать поведение ребенка». Подростки более склонны идеализировать картину родительства, предпочитают «не видеть» трудностей. 


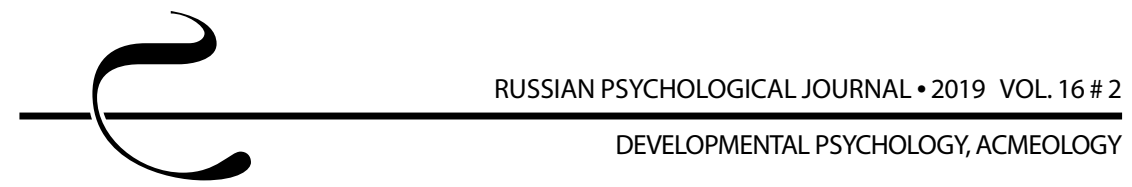

Выстраивая картину своего будущего родительства, они отдают предпочтение утверждениям: «мой ребенок никогда не будет капризничать», «у нас с супругом (супругой) не будет разногласий относительно воспитания ребенка», «все знают, как быть родителем, к этому не надо специально готовиться».

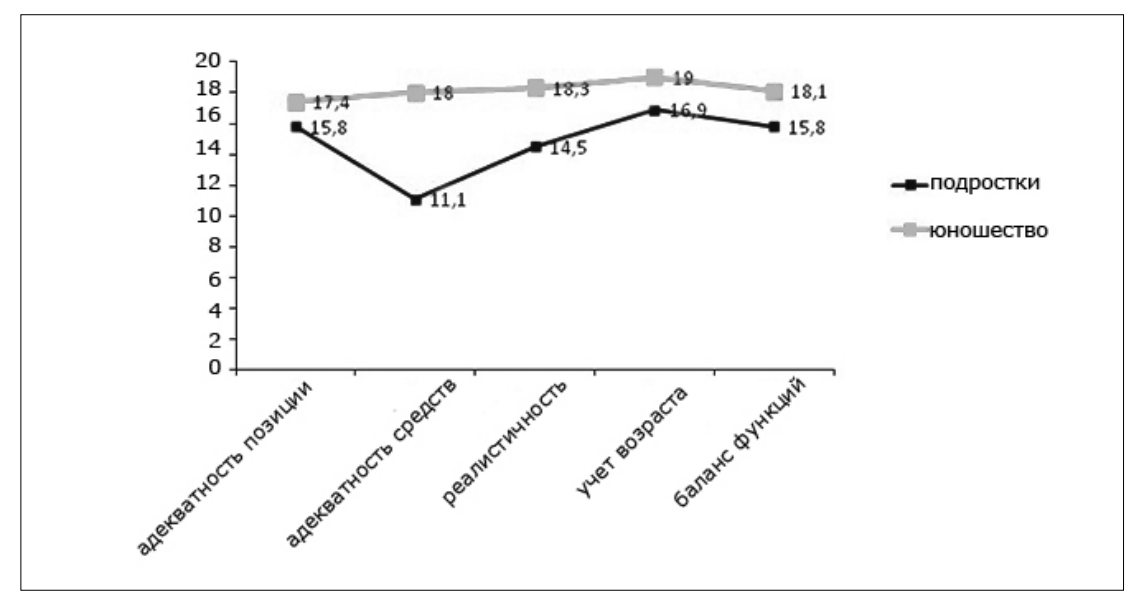

Рисунок 1. Средние значения шкал «Гармоничности представлений

о родительстве॥ в подростковой и юношеской выборке

Figure 1. Average values by the scales of the Consistency of Ideas About Parenthood questionnaire for the groups of adolescents and young adults

Результаты исследования позволяют говорить о недостаточной компетентности подростков относительно возрастных особенностей ребенка. Неучет ограничений возможностей ребенка, связанных с его возрастным развитием, позволяет подросткам соглашаться с утверждением о том, что «достаточно даже самому маленькому ребенку объяснить причину запретов, и он будет их соблюдать» или «я никогда не буду принимать решения за ребенка». Создается впечатление, что подростку представляется человек, соизмеримый по своим возможностям с собой. Непростым для подростков оказался вопрос о балансе родительских функций. Признавая абсолютный приоритет эмоционального принятия, родительской любви, они недооценивают функции ухода, воспитания и обучения. Так, подростки отстаивают мнение о всесилии родительской любви. Соглашаясь с тем, что «в воспитании ребенка главное - это любовь, а требования, запреты, контроль - второстепенны», они обнаруживают недостаточное знакомство с содержанием этой важнейшей родительской функции. Согласие с тем, что «интересное занятие с родителями для ребенка важнее, чем еда и сон», свидетельствует, на наш взгляд, о недооценке важности ухода 
за меленьким ребенком. Менее всего школьники оказались знакомы со средствами реализации родительских функций. Рисуя достаточно благополучную картину своего будущего с ребенком, подростки полагают, что «чтобы сделать ребенка счастливым, надо позволять ему делать то, что он хочет» или «ребенок вырастет добрым, если ему не отказывать во всех его желаниях». В то же время они сомневаются в том, что «чтобы ребенок выполнял требования родителей, необходим контроль» и «большое количество запретов мешает вырасти ребенку инициативным». Приведенные примеры свидетельствуют о наличии существенного количества искажений в представлениях подростков о родительстве.

Для молодых людей в целом характерны более адекватные, гармоничные представления о родительстве, его функциях и ролевой структуре. Особенно яркое отличие их от подростков лежит в сфере представлений о средствах воспитания: студенческая молодежь более компетентна в оценке средств воспитания и воздействия на ребенка $(T=-11,987, \mathrm{p}<0,001)$.

По результатам методики «Незаконченные предложения» (рис. 2) можно увидеть, что довольно большой процент как подростков (21 \%), так и молодых людей (25\%, четверть выборки), относится негативно к перспективе родительства: опрошенные не хотят иметь детей вообще никогда или собираются стать родителями не ранее, чем через 15-20 лет.

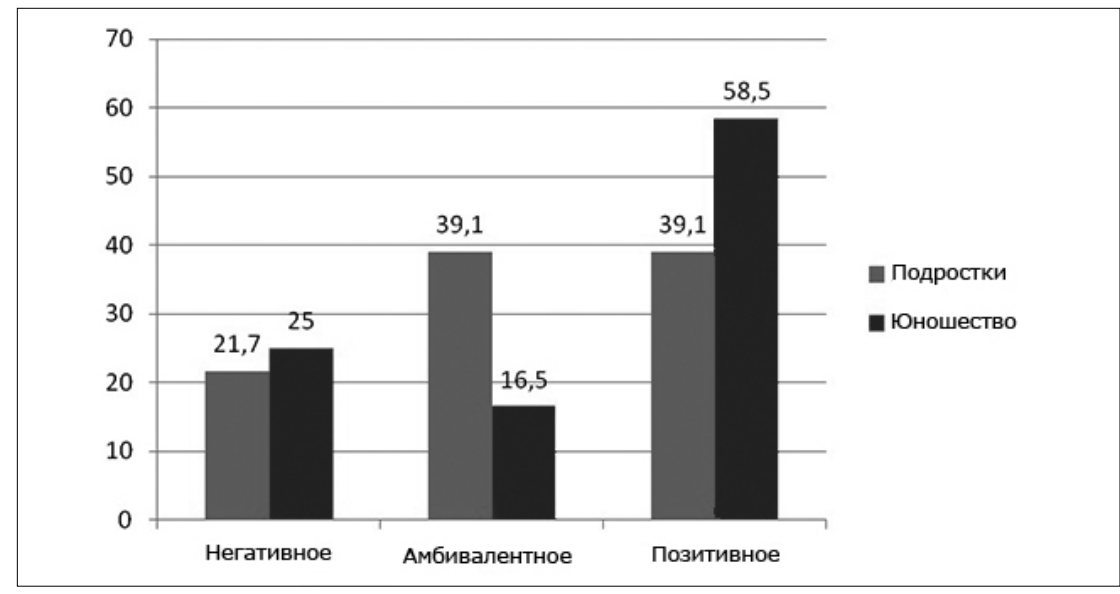

Рисунок 2. Отношение к родительству в целом в полростковом и юношеском возрасте

Figure 2. Attitudes towards parenthood in adolescence and young adulthood 
В то же время важно, что среди студентов наблюдается снижение доли амбивалентного отношения к материнству и отцовству в пользу положительного. Для подростков характерно именно амбивалентное отношение к родительству, что может свидетельствовать о том, что процесс самоопределения еще не завершен, и подросток рассматривает все «за» и «против», не придя еще к определенной позиции. На фоне признания значимости материнской роли в целом, они часто описывают его наступление как одновременно желанное и сложное, радостное и ущемляющее событие. Это согласуется с полученными в исследовании Абдуллиной (2018) свидетельствами повышенной тревожности подростков относительно родительства, даже в тех случаях, когда они выражают желание иметь ребенка в будущем.

К себе как к будущему родителю подростки относятся несколько хуже, чем к родительству вообще: 37,5 \% опрошенных оценивают себя как будущего родителя негативно и 29,2 \% - амбивалентно. Методика «Неоконченные предложения» проявила себя как достаточно чувствительная к системе отношений подростка. Продолжая неоконченное предложение «Сравнивая себя с идеалом матери/отца, могу сказать, что я...», некоторые подростки писали «на данный момент мои представления о материнстве и о способах общения с ребенком кажутся мне достойными того, чтобы стать хорошим родителем», «приближен к нему» (позитивное отношение), или «я не дотягиваю» (амбивалентное отношение). Предложение «Мне кажется, я буду...» подростки могли завершить как: «требовательной, но любящей матерью», «хорошим отцом» (позитивное отношение), так и «плохим отиом», «ужасной матерью» (негативное отношение). Завершая предложение «Представляя себя матерью (отцом)...», они писали «мне кажется, я буду понимать своего ребенка так же, как мои родители понимают меня», «я толстый, бородатый, веселый, надежный» (позитивное отношение), «становится страшно от груза ответственности» (амбивалентное отношение) или «у меня болит голова», «не хочу даже представлять» (отрицательное отношение). Высказывания в отношении нескольких предложений, составляющих единую шкалу, оказались согласованными, что облегчало диагностическую задачу и позволяло получить более достоверный результат.

Отношение подростков к будущему родительству согласуется с распределением приоритетных ценностей: только у $20 \%$ ценности родительства в приоритете, у 48 \% школьников отчетливо превалируют совершенно другие ценности. Полученный результат закономерен и вполне нормативен для выборки школьников, учитывая их актуальные задачи развития. Для старшеклассников сегодня на высоких местах в рейтинге расположены такие ценности, как обучение, аттестация, поступление в вуз, интимно-личностное общение со сверстниками. С ценностной направленностью значимо связано 
отношение подростков к родительству ( $p=0,019$ по критерию Хи-квадрат Пирсона $=11,756)$ и отношение к себе как к родителю ( $p=0,006$ по критерию Хи-квадрат Пирсона = 14,413). Мы видим, что высокая значимость ценности родительства становится условием становления позитивного отношения как к самому родительству, так и к себе как будущему родителю.

Представления о родительстве по методике «Незаконченные предложения» у $26 \%$ школьников можно описать как гармоничные, у $44 \%$ отличаются неполнотой, и 30 \% подростков демонстрируют дисгармоничные представления о родительстве («Хороший отец должен... не заводить детей»; «Самый лучший способ воспитания... бить и оскорблять ребенка»; «Хорошая мать должна... уметь стирать, убирать, готовить»; «Главная задача матери... воспитание культурного ребенка»; «Самое трудное в отцовстве... выжить»; «Самое трудное в отцовстве... всё»).

Зафиксированы гендерные различия старшеклассников по степени гармоничности представлений о родительстве: у мальчиков они более дисгармоничны и отличаются большей неполнотой. Схожие результаты были получены в современных российских исследованиях: на основании анализа сочинений старшеклассников было зафиксировано, что представления о содержании родительской сферы у девочек отличаются большей наполненностью и насыщенностью, как образа ребенка, так и образа родителя; психологический комфорт в позиции родителя у девочек выражен выше, чем у мальчиков (Абдуллина, 2018). В юношеском возрасте также существуют гендерные различия в представлениях о будущем родительстве: так, девушки показывают более высокую степень рефлексивности, чем юноши (Васильева, 2013).

Обратимся к наиболее предпочтительным типам реализации материнской роли, которые выбирают подростки (табл. 1). «Мама заботливая»- это тот образ, который большая часть выборки ставит на первые места. Это образ матери, для которой забота, внимание и уход за ребенком становятся центральной частью родительских функций. Но в то же время необходимо отметить, что для $10 \%$ старшеклассников этот образ оказался самым отвергаемым.

Женщина-мать, для которой материнская роль встраивается в сферу межличностного общения женщины вне семьи («мама общительная»), для которой социальное признание является наиболее значимым, оказалась наименее привлекательной: 72 \% опрошенных при ранжировании поставили данный способ реализации материнской роли на самое последнее место, и нет ни одного респондента, кто бы выбрал его в качестве предпочтительного. Важно отметить, что и абсолютно все подростки, не рассматривающие себя в качестве будущего родителя («отказывающиеся стать родителем»- $21 \%$ выборки), выбрали это изображение последним, т. е. совершенно непривлекательным. Можно отметить, что изображение женщины, сочетающей 
материнскую роль с супружеской («мама-жена»), ни один подросток не поставил на последнее место. Таким образом, самыми предпочитаемыми для подростков, т. е. отражающими их представления о том, какой же должна быть мать, являются изображения «мама заботливая», «мама-жена» и «мама хозяйственная». Эти результаты полностью согласуются с данными, полученными Долгих и Захаровой (2018) на выборке девушек-студенток. В данном случае не приходится говорить о возрастной специфике.

\begin{tabular}{|c|c|c|c|c|c|}
\hline \multicolumn{6}{|c|}{$\begin{array}{l}\text { Таблица } 1 \\
\text { Результаты ранжирования подростками предпочитаемых типов реализации } \\
\text { материнской роли } \\
\text { Table } 1 \\
\text { The results of ranking the preferred types of the implementation of maternal roles } \\
\text { among adolescents }\end{array}$} \\
\hline & 1 & $\underline{2}$ & $\underline{3}$ & $\underline{4}$ & $\underline{5}$ \\
\hline Образ матери & место & место & место & место & место \\
\hline Mother's image & $\underline{\underline{\text { place }}}$ & $\frac{\text { 2nd }}{\text { place }}$ & $\begin{array}{c}\frac{3 r d}{\text { place }} \\
\end{array}$ & $\begin{array}{l}\underline{4 t h} \\
\text { place }\end{array}$ & $\begin{array}{l}\frac{5 \text { th }}{\text { place }} \\
\end{array}$ \\
\hline $\begin{array}{l}\text { «Мама заботливая» } \\
\text { "Caring mother" }\end{array}$ & $48 \%$ & $31 \%$ & $3,5 \%$ & $3,5 \%$ & $10 \%$ \\
\hline $\begin{array}{l}\text { «Mама деловая» } \\
\text { "Mother/employee" }\end{array}$ & $17 \%$ & $3,5 \%$ & $34 \%$ & $31,5 \%$ & $10 \%$ \\
\hline $\begin{array}{l}\text { «Mама хозяйственная» } \\
\text { "Mother/homemaker" }\end{array}$ & $7 \%$ & $28 \%$ & $45 \%$ & $13,5 \%$ & $3,5 \%$ \\
\hline $\begin{array}{l}\text { «Maмa общительная» } \\
\text { "Sociable mother" }\end{array}$ & - & $13,5 \%$ & $3,5 \%$ & $7 \%$ & $72 \%$ \\
\hline $\begin{array}{l}\text { "Мама-жена» } \\
\text { "Mother/wife" }\end{array}$ & $25 \%$ & $21,5 \%$ & $10 \%$ & $42 \%$ & - \\
\hline
\end{tabular}

\section{Обсуждение результатов}

В целях анализа содержания представлений о родительской деятельности нами была разработана методика «Гармоничность представлений». Разработка была вызвана поиском компактных и достоверных средств выявления содержания представлений о родительстве. Эффективным средством для реализации указанной задачи является проективное сочинение. Однако в работе с подростками, для которых написание сочинения является достаточно сложной задачей, необходимо использовать средства, помогающие респондентам наиболее точно выразить свою позицию. Разработанная нами методика была позитивно воспринята старшеклассниками, оказалась понятной и достаточно удобной в использовании. 
В проведенном эмпирическом исследовании нам удалось зафиксировать и проанализировать имеющиеся у подростков и молодых людей представления о родительстве. Полученные результаты свидетельствуют о низкой гармоничности представлений в обеих возрастных группах. Кроме того, пятая часть обследуемых подростков и четверть молодых людей негативно относятся к перспективе своего будущего родительства. Наименее адекватные представления у подростков касаются средств воспитания ребенка, у юношей - адекватности родительской позиции.

Результаты исследования свидетельствуют о том, что подростковый возраст действительно является сенситивным для формирования представлений о будущем родительстве: нами были зафиксированы значимые различия по всем параметрам гармоничности представлений между обследуемыми возрастными группами. Несмотря на довольно низкие общие результаты, молодые люди более адекватно и реалистично оценивают себя как будущего родителя, больше учитывают возраст ребенка, более нормативны в выборе средств воспитания и имеют более адекватные представления о ролевой структуре родительства, чем подростки. Это согласуется с данными исследований о том, что именно юношеский возраст является сенситивным периодом для освоения поведенческого компонента представлений о родительстве (Абдуллина, 2018), а именно расширения представлений о средствах воспитания, обучения, ухода за детьми разного возраста.

Также среди студенческой молодежи растет определенность в отношении к родительству. Подростки демонстрируют большую долю амбивалентности в отношении к нему. Мы полагаем, что обследование было проведено в тот период, когда самоопределение в отношении родительства находится в начальной точке своего становления.

Bыводы:

1. Опросник «Гармоничность представлений о родительстве» обнаружил высокую валидность, показав согласованные с полученными посредством проективной методики данными.

2. Представления о будущем родительстве, как у подростков, так и у студенческой молодежи, отличаются низкой гармоничностью. Подростки наименее ориентированы в средствах достижения целей родительской деятельности, молодые люди обнаружили искаженное представление о родительской позиции, недостаточно дифференцируя ее от равноправной, дружеской. Полученные результаты позволяют определить направление гармонизирующего воздействия.

3. При переходе от подросткового возраста к юношескому происходит существенный сдвиг в содержании представлений о будущем родительстве. Последние приобретают большую определенность 
и адекватность. Это позволяет определить подростковый возраст в качестве сенситивного для гармонизирующего воздействия.

4. Спонтанное становление представлений о будущем родительстве у девушек опережает этот процесс у юношей.

5. В отношении к будущему родительству подростки обнаруживают большую долю амбивалентности, что свидетельствует о недостаточной определенности их жизненной позиции. Может быть рекомендовано усилить работу, направленную на повышение привлекательности родительства именно в этот возрастной период.

6. Наиболее привлекательным, как в выборке подростков, так и в юношеской выборке, является образ матери, олицетворяющей заботу о благополучии ребенка. Несмотря на то, что собственная перспектива родительства остается в большой степени неопределенной, в качестве идеального образа женщины-матери выступает та, что в наибольшей степени реализует функцию заботы и поддержки. Родительская роль в представлениях как подростков, так и молодых людей гармонично сочетается с супружеской.

7. Важнейшим условием становления отношения к родительству является формирование системы ценностных ориентаций. Высокая значимость ценности родительства согласуется у наших респондентов с позитивным отношением к материнству и отцовству и себе в качестве родителя.

\section{Благодарности}

Работа выполнена при финансовой поддержке РФФИ (проект № 18-01301213\19 «Роль художественной кинематографии в формировании установки на реализацию родительской деятельности и образа эффективного родительства у современной молодежи»).

\section{Acknowledgments}

This study was supported by the Russian Foundation for Basic Research (project no. 18-013-01213\19, "The role of the art of cinematography in forming attitudes towards the realization of parental activities and the image of effective parenthood at modern youth").

\section{Литература}

Абдуллина С. А. Представления о родительстве у детей дошкольного, младшего школьного и подросткового возраста: дисс. ... канд. психол. наук. М., 2018. 280 с. Васильева $E$. Н. Гендерные различия в структурных компонентах психологической готовности к родительству // Современные проблемы науки и образования. 2013. № 6. URL: www.science-education.ru/113-11341 (дата обращения: 29.08.2018). 
Васягина Н. Н. Субъективное становление матери в современном социокультурном пространстве России: дисс. ... д-ра психол. наук. Екатеринбург, 2011. 464 с.

Девятых С. Ю. Особенности представлений о родительстве в юношеском возрасте (анализ гендерных различий): дисс. ... канд. психол. наук. Смоленск, 2006. 231 с.

Долгих А. Г., Захарова Е. И. Психологические особенности образа материнства у девушек в период вхождения во взрослость // Мир психологии. 2018. № 1 (93). С. 155-163.

Долгих А. Г., Захарова Е. И. Содержание и степень гармоничности представлений о материнстве и отцовстве в юношеском возрасте // Вестник Московского университета. Серия 14: Психология. 2018. № 2. С. 89-99. DOI: $10.11621 / v s p .2018 .02 .89$

Захарова Е. И. Представление о характере социальной роли, как средство ориентировки в ее исполнении // Культурно-историческая психология. 2012. № 4. С. 38-41.

Захарова Е. И. Психология освоения родительства: научная монография. М.: Изд-во ИИУ МГОУ, 2014. 258 с.

Захарова Е. И. Условия становления негативного отношения современных женщин к материнской роли // Культурно-историческая психология. 2015. T. 11, № 1. С. 44-49.

Карабанова О. А. Психология семейных отношений и основы семейного консультирования. М.: Гардарики, 2005. 320 с.

Крысько А. А., Ланцбург М. Е. Представления о материнстве и возрастных особенностях детей у девушек старшего подросткового возраста // Психологическая наука и образование psyedu.ru. 2014. Т. 6, № 2. С. 129-138. DOI: $10.17759 /$ psyedu.2014060211

Левченко А. В. Представления о собственном отцовстве у мужчин и факторы, их обусловливающие: дисс. ... канд. психол. наук. Краснодар, 2009. 194 с. Манёров Р. В. Образ себя как отца в структуре Я-концепции мужчин: дисс. ... канд. психол. наук. СПб., 2013. 213 с.

Мерзлякова С. В. Родительская семья как ориентирующий образ семейного самоопределения молодежи // Теория и практика общественного развития. 2014. № 2. С. 114-119.

Мухина Н. В., Белогай К. Н. Уровень психологической готовности к материнству в период ранней взрослости // Перинатальная психология и психология родительства. 2007. № 4. С. 98-100.

Овчарова Р. В. Психология родительства. М.: Академия, 2005. 368 с.

Павлова Т. В. Психологические механизмы формирования зрелых представлений о родительстве // Вестник университета (Государственный университет управления). 2011. № 16. С. 77-78. 


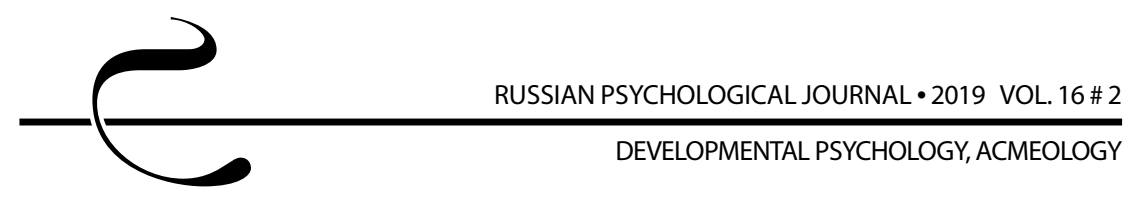

Пальчева Т.В. Психологические условия становления и развития репродуктивных установок в детско-юношеском возрасте: дисс. ... канд. психол. наук. М., 2006. 156 c.

Поливанова К. Н. Современное родительство как предмет исследования // Психологическая наука и образование psyedu.ru. 2015. Т. 7, № 3. С. 1-11. DOI: $10.17759 /$ psyedu. 2015070301

Психология родительства: подходы, проблемы, методы исследования / под ред. Е. В. Куфтяк. Кострома: Изд-во КГУ им. Н. А. Некрасова, 2006. 142 с.

Родители и дети: психология взаимоотношений / под ред. Е. А. Савиной, Е. О. Смирновой. М.: Когито-Центр, 2003. 228 с.

Филиппова Г.Г. Психология материнства: учебное пособие. М.: Изд-во Института Психотерапии, 2002. 240 с.

Филиппова Г. Г. Развитие родительской сферы в онтогенезе и готовность к материнству // Психология беременности, родов и послеродового периода: хрестоматия по перинатальной психологии / сост. А. Н. Васина. М.: Университет Российского инновационного образования, 2005. С. 62-65. Arendell T. Conceiving and investigating motherhood: The decade's scholarship // Journal of Marriage and Family. 2000. Vol. 62, Issue 4. P. 1192-1207. DOI: 10.1111/j.1741-3737.2000.01192.x

Cudmore L. Finding a place for the baby: complexity and congestion in the transition to parenthood // International Journal of Infant Observation and Its Applications. 2012. Vol. 15, Issue 1. P. 77-90. DOI: $10.1080 / 13698036.2012 .654657$

Delmore-Ko P., Pancer S. M., Hunsberger B., Pratt M. Becoming a parent: The relation between prenatal expectations and postnatal experience // Journal of Family Psychology. 2000. № 14. P. 625-640.

Hakim C. Models of the Family in Modern Societies: Ideals and Realities. Ashgate Pub Ltd, 2003. 282 p.

Langdridge D., Sheeran P., Connolly K. Understanding the reasons for parenthood // Journal of Reproductive and Infant Psychology. 2005. Vol. 23, Issue 2.

P. 121-133. DOI: $10.1080 / 02646830500129438$

Modern Parenthood. Roles of Moms and Dads Converge as They Balance Work and Family // Pew Research Center: Social \& Demographic Trends. 2013. Available at: https://www.pewsocialtrends.org/2013/03/14/modern-parenthoodroles-of-moms-and-dads-converge-as-they-balance-work-and-family/ (Accessed 26.05.2019).

Oechsle M., Zoll R. Young people and their ideas on parenthood // European Parents in the 1990s: Contradictions and Comparisons. New Brunswic, New Jersey: Trasaction Publishers, 1991. P. 45-58.

Richards N. The Ethics of Parenthood. New York: Oxford University Press, 2010. 304 p. Salmela-Aro K., Nurmi J. E., Saisto T., Halmesmäki E. Women's and men's personal 
goals during the transition to parenthood // Journal of Family Psychology. 2000. Vol. 14 (2). P. 171-186.

\section{References}

Abdullina, S. A. (2018). Concept of parenthood in preschool-age children, primary school-aged children and adolescents (Doctoral dissertation). Moscow. (in Russ.).

Arendell, T. (2000). Conceiving and investigating motherhood: The decade's scholarship. Journal of Marriage and Family, 62(4), 1192-1207. doi: 10.1111/j.1741-3737.2000.01192.x

Cudmore, L. (2012). Finding a place for the baby: Complexity and congestion in the transition to parenthood. International Journal of Infant Observation and Its Applications. 15(1), 77-90. doi: 10.1080/13698036.2012.654657

Delmore-Ko, P., Pancer, S. M., Hunsberger, B., \& Pratt, M. (2000). Becoming a parent: The relation between prenatal expectations and postnatal experience. Journal of Family Psychology, 14, 625-640.

Devyatykh, S. Yu. (2006). Specific aspects of perceptions of parenthood in adolescence: Analysis of gender differences (Doctoral dissertation). Smolensk. (in Russ.).

Dolgikh, A. G., \& Zakharova, E. I. (2018). Psychological features of the image of motherhood in girls in the period of entering into adulthood. Mir psikhologii (World of Psychology), 93(1), 155-163. (in Russ.).

Dolgikh, A. G., \& Zakharova, E. I. (2018). The content and degree of harmony of ideas about motherhood and fatherhood in youth. Vestnik Moskovskogo universiteta. Seriya 14: Psikhologiya (Moscow University Psychology Bulletin), 2, 89-99. doi: 10.11621/vsp.2018.02.89 (in Russ.).

Filippova, G. G. (2002). Psychology of motherhood. Moscow: Izd-vo Instituta Psikhoterapii. (in Russ.).

Filippova, G. G. (2005). The development of the parent sphere in ontogenesis and willingness to motherhood. In A. N. Vasina (Ed.), The psychology of pregnancy, childbirth and the postpartum period: Readings in perinatal psychology (pp. 62-65). Moscow: Russian Innovation University of Education.

Hakim, C. (2003). Models of the family in modern societies: Ideals and realities. Aldershot: Ashgate.

Karabanova, O. A. (2005). Psychology of family relations and the basics of family counseling. Moscow: Gardariki.

Krys'ko, A. A., \& Lantsburg, M. E. (2014). Representation of motherhood and age characteristics of infants in girls in their late teens. Psikhologicheskaya nauka i obrazovanie (Psychological Science and Education psyedu.ru), 6(2), 129-138. doi: $10.17759 /$ psyedu.2014060211 (in Russ.).

Kuftyak, E. V. (Ed). (2006). Psychology of parenthood: Approaches, issues, and research methods. Kostroma: Izd-vo KGU im. N. A. Nekrasova. (in Russ.). 


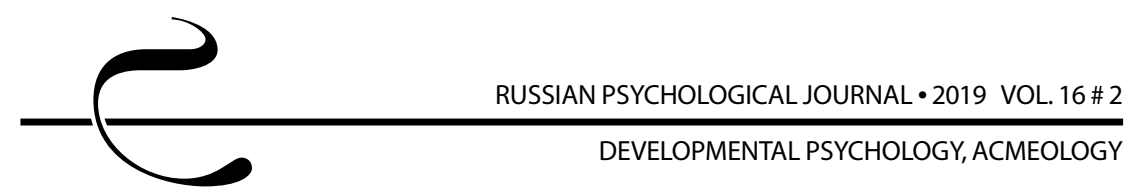

Langdridge, D., Sheeran, P., \& Connolly, K. (2005). Understanding the reasons for parenthood. Journal of Reproductive and Infant Psychology, 23(2) 121-133. doi: 10.1080/02646830500129438

Levchenko, A. V. (2009). Men's ideas about their fatherhood and their underlying factors (Doctoral dissertation). Krasnodar. (in Russ.).

Manerov, R. V. (2013). Self-image as a father in the structure of the self-concept of men (Doctoral dissertation). St. Petersburg. (in Russ.).

Merzlyakova, S. V. (2014). Parental family as a guideline image of youth's family identity. Teoriya i praktika obshchestvennogo razvitiya (Theory and Practice of Social Development), 2, 114-119. (in Russ.).

Mukhina, N. V., \& Belogai, K. N. (2007). The level of psychological readiness to mothering in early adulthood. Perinatal'naya psikhologiya i psikhologiya roditel'stva (Perinatal Psychology and Psychology of Parenthood), 4, 98-100. (in Russ.).

Oechsle, M., \& Zoll, R. (1991). Young people and their ideas on parenthood. In U. Björnberg (Ed.), European Parents in the 1990s: Contradictions and Comparisons (pp. 45-58). New Brunswic, New Jersey: Trasaction Publishers.

Ovcharova, R. V. (2005). Psychology of parenthood. Moscow: Akademiya. (in Russ.).

Pal'tseva, T. V. (2006). Psychological conditions of the formation and development of reproductive attitudes in childhood and adolescence (Doctoral dissertation). Moscow. (in Russ.).

Pavlova, T. V. (2011). Psychological mechanisms of the formation of mature ideas about parenthood. Vestnik universiteta, 16, 77-78. (in Russ.).

Pew Research Center: Social \& Demographic Trends. (2013). Modern parenthood. Roles of moms and dads converge as they balance work and family. Retrieved from https://www.pewsocialtrends.org/2013/03/14/modern-parenthoodroles-of-moms-and-dads-converge-as-they-balance-work-and-family/

Polivanova, K. N. (2015). Moderm parenthood as a subject of research. Psikhologicheskaya nauka i obrazovanie (Psychological Science and Education psyedu.ru), 7(3), 1-11. doi: 10.17759/psyedu.2015070301 (in Russ.).

Richards, N. (2010). The ethics of parenthood. New York: Oxford University Press.

Salmela-Aro, K., Nurmi, J. E., Saisto, T., \& Halmesmäki, E. (2000). Women's and men's personal goals during the transition to parenthood. Journal of Family Psychology, 14(2), 171-186.

Savina, E. A., \& Smirnova, E. O. (Eds). (2003). Parents and children: Psychology of relationships. Moscow: Kogito-Tsentr. (in Russ.).

Vasil'eva, E. N. (2013). Gender differences in structural components of psychological readiness for parenthood. Modern Problems of Science and Education, 6. Retrieved from www.science-education.ru/113-11341 (in Russ.).

Vasyagina, N. N. (2011). Subjective becoming a mother in today's socio-cultural space of Russia (Doctoral dissertation). Ekaterinburg. (in Russ.). 
Zakharova, E. I. (2012). Ideas about social role characteristics as means of orientation in its performance. Kul'turno-istoricheskaya psikhologiya. (Cultural-Historical Psychology), 4, 38-41. (in Russ.).

Zakharova, E. I. (2014). Psychology of mastering parenthood. Moscow: Izd-vo IIU MGOU. (in Russ.).

Zakharova, E. I. (2015). Conditions for formation of modern women's negative attitudes towards a maternal role. Kul'turno-istoricheskaya psikhologiya (CulturalHistorical Psychology), 11(1), 44-49 (in Russ.). 